Wloclawek, Republic of Poland

July $9-10,2021$

DOI https://doi.org/10.30525/978-9934-26-110-7-75

\title{
МОВЛЕННЄВИЙ АКТ КОМПЛІМЕНТУ В ПЕРСЬКОМОВНОМУ КОМУНІКАТИВНОМУ ПРОСТОРІ
}

\author{
Мазепова О. В. \\ доктор філологічних наук, дочент, \\ завідувач кафедри мов і літератур Близького та Середнього Сходу \\ Інституту філології \\ Київський національний університет імені Тараса Шевченка \\ м. Київ, Украӥна
}

Поняття мовленнєвого акту (МА) стало одним із найбільш продуктивних понять лінгвістики XX ст., яке увійшло до наукового обігу наприкінці 50-х років минулого століття завдяки концепції британського філософа Джона Остіна. Після виходу в світ його книги «How to do things with words» (1962 р.) ця концепція була взята на озброєння науковим товариством і згодом доопрацьована такими дослідниками, як Дж. Серль, П. Стросон, П. Грайс, Дж. Ліч, Й. Мейбауер, Д. Шпербер, А. Вежбицька, М. Нікітін, Г. Почепцов та ін. У межах сучасної комунікативно-функціональної парадигми в лінгвістиці теорія МА не втрачає своєї актуальності, оскільки слугує зручним інструментом дослідження комунікативної поведінки представників різних лінгвокультур, що становить неабиякий інтерес для вирішення проблем міжкультурної комунікації.

Перськомовна комунікативна поведінка значною мірою регулюється іранським етикетним комплексом $\boldsymbol{t a}$ 'ärof, який інколи розглядається дослідниками як система ввічливості [4]. На нашу думку, іранський комплекс ta'ärof варто розуміти як дещо більше, ніж систему ввічливості, оскільки він охоплює багато аспектів, які не лише покривають соціальну взаємодію іранців між собою, а й значною мірою впливають на перебіг їхньої комунікації з представниками інших народів.

Метою даної розвідки є встановлення етноспецифіки функціонування МА компліменту в перськомовному комунікативному просторі з огляду на регулятивні особливості етикетного комплексу $\mathbf{t a}$ 'ärof.

Значний внесок у розвиток теорії МА зробили американські соціолінгвісти П. Браун і С. Левінсон, які на її основі запропонували власну концепцію лінгвістичної ввічливості, заснованої на принципі «збереження обличчя» [2]. Дослідники визначали «обличчя» як універсальне поняття, певний соціальний імідж, про який має піклуватися кожен дорослий член суспільства [2, с. 60-61]. При цьому саме поняття 
«обличчя» в їхній концепції має два аспекти: «позитивне обличчя» (positive face) i «негативне обличчя» (negative face). Позитивний аспект обличчя полягає у бажанні людини бути схваленим іншими людьми, а негативний - y iï прагненні зберігати свободу дій i не припускати втручання інших людей у своє життя [2, с. 62]. Під час соціальної інтеракції, як зазначають дослідники, задля досягнення запланованого комунікативного ефекту комуніканти повинні дбати про те, щоб не зашкодити обличчю свого партнера, особливо в ситуаціях, коли виникає така небезпека. Тому вони виокремили і класифікували так звані facethreatening acts (FTA) - тобто МА, що загрожують обличчю мовця або його співрозмовника, і прописали тактики, покликані зменшити або зовсім нівелювати такі загрози.

Згідно $з$ цією концепцією, загрозу позитивному обличчю мовця несуть такі МА, як вибачення, визнання провини або відповідальності, прийняття компліменту; загрозу негативному обличчю мовця - МА подяки, прийняття пропозиції, виправдання, вибачення, обіцянки або пропозиції. Загроза позитивному обличчю слухача міститься в таких МА, як критика, несхвалення, звинувачення, насмішка, образа, незгода, виклик тощо; загроза його негативному обличчю - в таких МА, як наказ, прохання, порада, нагадування, погроза тощо. Крім того, до загрозливих для обличчя співрозмовника МА дослідники відносять пропозиції і обіцянки, які можуть викликати у слухача відчуття зобов'язання, а також МА компліменту, що може створити певний дискомфорт для співрозмовника, зокрема через підозру, що мовець бажає заволодіти предметом, що йому не належить [2, с. 65-68].

Назва праці П. Браун і С. Левінсон «Politeness: Some Universals in Language Usage» (1987) засвідчує, що дослідники претендували на те, що запропоновані ними універсалії властиві усім системам ввічливості світу. Проте майже одразу після опублікування праці почали з'являтися критичні відгуки, особливо з боку дослідників східних систем ввічливості, які ставили під сумнів «універсальність» запропонованих аспектів позитивного і негативного - поняття обличчя і відзначали «західноцентричність» самої концепції. Зокрема деякі дослідники $[3 ; 4 ; 6 ; 7]$ підкреслювали, що в східних культурах найбільше значення для індивіда має не так захист своєї автономності і особистої свободи («негативне обличчя» у термінах П. Браун і С. Левінсона), як приналежність до певної групи і піклування про місце, яке він займає в соціальній ієрархії. Дослідники перської системи ввічливості так само віддали данину критиці окресленої вище концепції [5, с. 29-31; 8, с. 96 та ін.]. Проте, на нашу думку, ця концепція $є$ цінною передусім 3 методологічного 
погляду, адже іiї зручно брати за основу як певну точку відліку не тільки при дослідженні комунікативної поведінки представників окремих лінгвокультур, а й при проведенні кроскультурних студій.

Отже, комплімент, на думку П. Браун і С. Левінсона, відноситься до «загрозливих» МА, причому він несе загрозу як обличчю мовця (МА висловлення компліменту), так і обличчю його співрозмовника (МА прийняття компліменту), оскільки може викликати неоднозначну реакцію візаві або накласти на нього певні зобов'язання. Якщо ж ми придивимося до перськомовної комунікативної культури, то побачимо, що комплімент є невід'ємним складником повсякденного ввічливого спілкування. Найбільш яскраво це виявляється при аналізі такої культурної схеми, як šekastenafsi (букв. 'ламання себе': šekaste 'зламаний' + nafs 'сам' + морфологічний показник -i), що умовно перекладається як «скромність». Обмін компліментами, який має місце під час застосування цієї культурної схеми іранцями, передбачає комбінування стратегій самоприниження із стратегіями піднесення обличчя співрозмовника і виникає як під час спілкування в офіційних установах, так і в родині [дет. див.: 1].

Найбільш етноспецифічною в перськомовній комунікативній культурі $є$ тактика «відкидання компліменту», суть якої полягає в тому, що комунікант, отримавши комплімент, має всіляко заперечувати свою заслугу або участь у тому, що є об'єктом компліменту, пояснюючи це збігом обставин, допомогою близьких людей, членів родини, волею Всевишнього тощо, і одразу переводити його на адресу свого візаві. Тобто необхідно не лише скромно заперечити своє досягнення і таким чином принизити своє «Я», а й підвищити «Я» свого партнера по комунікації, зробивши йому комплімент у відповідь. Таке «повернення» компліменту сприяє збереженню обличь обох комунікантів, оскільки демонструє їхне виховання і знання прийнятих у суспільстві правил спілкування.

Варто зазначити, що іранці можуть переносити елементи цієї культурної схеми на спілкування в умовах міжмовної взаємодії. Цей факт описує австралійський дослідник іранського походження Ф. Шаріфіян, наводячи як приклад діалог, який відбувся між студентоміранцем та його англомовним викладачем:

Lecturer: I heard you've won a prestigious award. Congratulations! This is fantastic.

Student: Thanks so much. I haven't done anything. It's the result of your effort and your knowledge. I owe it all to you. 
Lecturer (appearing uncomfortable): Oh, no!!! Don't be ridiculous. It's all your work [8, c. 103].

Як бачимо з цього діалогу, спроба студента заперечити власне досягнення і пояснити його заслугою викладача спричинила певний дискомфорт для останнього, оскільки, виходячи з західної, англосаксонської культурної схеми, заснованої на шануванні особистих заслуг, він відчув, що його внесок в успіх студента явно перебільшений, і студент, очевидно, просто хоче йому полестити. Натомість студент лише діяв у рамках своєї культурної схеми і практикував комбінування тактик самоприниження власного обличчя і підвищення обличчя співрозмовника, що $є$ рутинним в умовах перськомовного спілкування.

Отже, як можна виснувати з вищенаведеного, під час міжкультурної комунікації 3 представниками перської лінгвокультури необхідно враховувати те, що деякі МА, які кваліфікуються в концепції П. Браун i С. Левінсона як загрозливі, не $\epsilon$ такими в перськомовному комунікативному просторі. Одним із таких МА $є$ комплімент, який в даному разі можна кваліфікувати не як загрозливий МА, а як такий, що сприяє гармонійному спілкуванню.

Детальне вивчення всіх нюансів функціонування таких «неоднозначних» МА в лінгвокультурі країни партнера може стати запорукою успішної комунікації з ним.

\section{Література:}

1. Мазепова О. В. Культурна схема ŠEKASTENAFSI (самоприниження) у складі перської системи ввічливості ta'àrof. Мовні $i$ концептуальні картини світу. 2016. Вип. 57. С. 241-249.

2. Brown P., Levinson S. Politeness: Some Universals in Language Usage. Cambridge: Cambridge University Press, 1987. 358 p.

3. Gu Y. Politeness phenomena in modern Chinese. Journal of Pragmatics. 1990. Vol. 14(2). P. 237-257.

4. Ide S. Formal forms and discernment: two neglected aspects of universals of linguistic politeness. Multilingua. 1989. Vol. 8(2-3). P. 223-248.

5. Koutlaki S. A. The Persian system of politeness and the concept of face in Iranian culture. 1997. URL: https://www.academia.edu/21199856/The _ politeness_system_taarof_and_the_concept_of_face_in_Iranian_culture (дата звернення: 05.07.2021.)

6. Mao L. R. Beyond politeness theory: 'face' revisited and renewed. Journal of Pragmatics. 1994. 21: 451-486.

7. Matsumoto Y. Re-examination of the universality of face: politeness phenomena in Japanese. Journal of Pragmatics. 1988. 12: 403-426. 
8. Sharifian F. Cultural conceptualisations in learning English as an L2: Examples from Persian-speaking learners. Iranian Journal of Language Teaching Research. 2013. 1(1): 90-116.

DOI https://doi.org/10.30525/978-9934-26-110-7-76

\title{
МІЖКУЛЬТУРНА КОМУНІКАЦІЯ ЗМІНИ У ВИКОРИСТАННІ УГОРСЬКОЇ МОВИ ЗА КОРДОНОМ
}

\author{
Нодь Н. Й. \\ кандидат філологічних наук, \\ доиент кафедри угорської філологіі \\ Ужгородський національний університет \\ м. Ужггород, Украӥна
}

Мовна мінливість означає, що даний мовний елемент може виражатися в різних варіаціях і, отже, у тісно пов'язаних між собою мовних варіантах. Іншими словами, жодна людина 3 однаковою рідною мовою не могла б завжди говорити одне і те ж за однакових обставин [1, с. 12-25.]. Відмінності випливають насамперед із середовища та громади, де вони виростають. Дослідження Леслі та Джеймса Мілрой у Белфасті першими довели, що коли члени мають набагато більше контактів між собою, ніж із сторонніми, поведінка членів визначається більш сильними нормами, а повага до власних норм стає дуже сильною. [3, с. 19-36.] Результати показують, що якщо хтось інтенсивніше інтегрується у своє співтовариство, він буде використовувати більше нестандартних версій, характерних для цієї групи. Один із результатів, досягнутий Пітером Трудгіллом з Нориджа, продемонстрував, що хоча оцінка версії стандартної мови є безсумнівною, досліджувані громади прив'язані до своєї мовної версії, навіть якщо вони вже зазнали негативної дискримінації. [4, с. 43-54.] Метою дослідження є пошук характеристик, що характеризують вживання мови молодшої людини, яка переїхала до Угорщини. Розширення дослідження на більше транскордонної інформатики, ніж у попередньому дослідженні, і доповнення існуючих даних особистими життєвими історіями, індивідуальним досвідом, поясненнями, розповідями та звітами про життєвий шлях. Ми вважаємо важливим спостерігати за мовними явищами, які висунулися на перший план під час інформативного мовленнєвого досвіду в Угорщині, та в рамках подальшого дослідження, щоб підкреслити, чи 